\title{
Price Measures for Semiconductor Devices
}

\author{
Ana Aizcorbe* \\ Board of Governors of the Federal Reserve System \\ $20^{\text {th }} \&$ C Streets, NW \\ Washington, DC 20551 \\ (202) 452-3152 \\ aaizcorbe@frb.gov
}

January 2001

Revised January 2002

\begin{abstract}
This note provides quality-adjusted price indexes and nominal shipments data for highly disaggregate classes of selected semiconductor devices. These data may be used to construct indexes under different assumptions from those in currently available indexes. Because the construction of these building blocks require some assumptions, the indexes are compared with similar price measures constructed by Bruce Grimm (1998) and by the Bureau of Labor Statistics.
\end{abstract}

\footnotetext{
*The views presented here are solely those of the author and do not necessarily reflect the views of the staff or members of the Board of Governors of the Federal Reserve System. These indexes were constructed as part of a larger IT project spearheaded by Carol Corrado at the Federal Reserve Board. Special thanks to Carol Corrado and to Bruce Grimm, and Mike Holdway for many useful discussions. Helpful comments were also provided by Doug Andrey (SIA), Ellen Dulberger (IBM), Ken Flamm, Fred Merkle (BLS), Charlie Gilbert, and James Seay (Dataquest, Inc.). Research assistance was ably provided by Meredith Krug, Mike St.Clair, and Matt Wilson.
} 


\section{INTRODUCTION}

This paper provides highly disaggregate measures of constant-quality price change and nominal shipments for selected semiconductor devices that may be used to construct more aggregate measures of price change under a variety of assumptions and methods. An appendix details the data sources and construction of the measures and gives tabulations of the measures. Below, the new measures are aggregated to a level that allows comparisons with existing measures published by statistical agencies. These comparisons are made to highlight the numerical importance of differing assumptions and data sources.

Building on work by Bruce Grimm (1998), quality-adjusted measures for chips in the MOS memories and microprocessor segments are constructed for the period 19921999. For the remaining segments, indexes are constructed for as many devices as the existing data allow. All these sub-indexes are chained, matched-model indexes that use either the Fisher or geometric means formula, depending on the available data. The "Matched-model" technique generates a quality-adjusted price index, while the Fisher index formula ensures that the appropriate weights are used to aggregate over goods. Absent revenue data with which to form the Fisher weights, chained geometric means are calculated instead. For the most part, the data are high-frequency data on prices and quantities of chips at a very disaggregate level.

Turning to the top line, the most aggregate index considered here is a price deflator for semiconductors as a whole-most of the products in the old SIC3674. ${ }^{1}$ Table 1 compares growth rates for annual averages of this aggregate-labeled "new" to the comparable BEA and BLS measures. Both the new and BEA indexes use chained-Fisher weights, but aggregate over different subindexes; while the new index aggregates over mostly chained-Fisher subindexes, BEA aggregates over the Laspeyres subindexes

1 Table $\mathrm{Al}$ in the appendix details the individual semiconductor devices covered by this index. 2 Strictly speaking, the annual averages discussed in the text are not properly constructed indexes. As shown in Diewert (2000), annual averages do not weight the high-frequency observations properly. As such, the annual averages in the text should be viewed as a descriptive statistic for the properly-constructed high-frequency indexes in the appendix. 
constructed by the BLS. Comparing the two indexes shows the effect that these differences in the underlying subindexes have on the top line: The new index falls 15-20 percentage points faster than the BEA index in 1997 and again in 1998. Similarly, both the BEA and PPI measures aggregate over the same subindexes, but use different aggregation formulas; the BEA uses a chained Fisher formula while the BLS uses a fixedweight laspeyres. Comparing those two measures shows the effect that different aggregation formulas have on the top line: the BEA index falls 15-30 percent faster than the PPI.

Comparisons at finer levels of disaggregation are discussed below and organized into three coarse market segments: MOS memory chips (like DRAM), MOS logic and microcomponents (including microprocessors like the Pentium III), and everything else (other integrated circuits, opto-electronics, and discrete devices). Of the three segments, the MOS logic and microcomponents segment is the largest in global markets and makes up nearly one-half of the world's production; each of the other two segments make up about one-quarter of world shipments.

\section{MOS MEMORY CHIPS}

MOS memory chips are devices intended to store data and are used in a variety of applications, ranging from the personal computer (PC) to digital alarm clocks. In 1999, these devices made up 25 percent of the dollar value of all chips produced in the world and 20 percent of the value of chips produced in the US. This segment of semiconductor markets continues to show rapid rates of product innovation and technological change.

Indexes for five types of MOS memory devices were constructed for the period 1992 to 1999 . Table 2 compares the resulting indexes to those constructed by Bruce Grimm (1998). Both indexes tell the same story for MOS memories as a whole: both show small changes for prices in each year between 1993 to 1995 followed by sharp declines in prices in 1996. Measures for some of the underlying segments are also very similar: DRAM, EEPROM, EPROM. 
These similarities in the numerical estimates stem from similarities in the methods used and the underlying data. Both the Grimm and new indexes for these devices are matched-model chained Fisher indexes applied to highly detailed data. Both are indexes for the world market- they both use worldwide nominal shipments data to form the aggregation weights. Both use data from the same source, but the frequencies are different: data used here are quarterly while the data used by Grimm are annual.

Estimates for the remaining devices differ somewhat, owing to differences in the level of aggregation in the underlying raw data. The Grimm indexes for Flash and SRAM memory are superior to those used here in that they are constructed using (discontinued) data that has a finer level of product detail. For SRAM, table 2 shows the two indexes constructed by Grimm—one for "fast" SRAM and one for "slow" SRAM. Though the differences are nontrivial, the nominal weights for Flash and SRAM are still sufficiently small that the effect on the top line is small.

Chart 1 compares two aggregates of these memory indexes to Producer Price Indexes over the period 1997 to 1999; a comparison for the earlier period is not made because the PPI methodology for these devices was improved beginning in 1997, making the data before 1997 not comparable to the more recent data. The measures labeled "world" are aggregates of the world subindexes shown in table 2, where the aggregation is done using world nominal shipments; the measures labeled "US" are also aggregates of the world subindexes, but the aggregation is done using US nominal shipments data from Census' published Current Industrial Reports for semiconductor devices.

In 1997-98, the memory aggregates fall between 45 and 55 percent while the PPI falls less than 30 percent; and in 1999, the new measures fall about 20 percent while the PPI actually rises. These differences reflect the many differences in the construction and data sources of the two measures. As is the case with all PPI measures, the PPI for semiconductors contains some substitution bias-because it uses a Laspeyres formulaand may not introduce goods quickly enough to capture the very steep price declines early in a chip's life. With regard to data sources, though, the subindexes constructed here rely 
on worldwide shipments for weights and those shipments may not adequately reflect the composition of US production.

Parsing out the differences into the underlying types of memory chips, the differences in the overall indexes stem from gaps in the underlying price indexes for both DRAM - shown in the left, bottom panel-and memory chips other than DRAM-shown at the right. For DRAM, the differences could, in part, reflect the broader coverage of the PPI for DRAM. The PPI covers both contract and spot markets-the latter makes up about 10 percent of the world market-whereas the index used here only covers contract prices. This problem in coverage is not innocuous because contract prices-negotiated in advance - probably respond more sluggishly than spot market prices to changes in the underlying fundamentals. Still, to explain the gap, spot prices would have had to have fallen substantially slower than contract prices and that seems unlikely-transactions in the spot market make up only about 10 percent of the MOS memories market.

\section{MOS LOGIC AND MICROCOMPONENTS}

The most widely known and most important type of logic and microcomponent chip is the microprocessor-like Intel's Pentium. In 1999, microprocessors (MPUs) made up 21 percent of the dollar value of all chips produced in the world and 51 percent of the value of chips produced in the US; the weight is heavier in US markets because Intel-the dominant firm in MPU market-produces most of its logic chips in the US.

The remainder of the MOS logic and microcomponent segment is a bucket, covering devices that are very diverse both in terms of technology and uses. These "other logic chips" are also important - taken together, they made up 35 and 14 percent of the world and US markets in 1999, respectively, and are expected to outpace the growth in microprocessor market in coming years. Like microprocessors, these devices show rapid rates of product innovation and technological change.

The first building block for a price index for this segment is the index for microprocessors provided in Aizcorbe, Corrado and Doms (2000). The first two columns of table 3 compare the measure constructed by Grimm to the ACD measure for all Intel microprocessors, including servers. The numerical differences reflect differences in both 
method and coverage: The Grimm measure is partially based on hedonic techniques and covers all non-embedded chips - those produced by both Intel and its rivals-while the ACD measure is a chained Fisher that only covers Intel's chips-about 90 percent of the dollar value of worldwide sales over this period. Despite the narrower coverage of the $\mathrm{ACD}$ measure, one could argue that it is preferable because the quality of data on Intel is superior to that of other firms. Importantly, disaggregate shipments data with which to compute weights are not available for Intel's rivals.

Though these non-embedded chips-typically used in personal computers-have historically dominated the MPU segment, embedded chips are growing rapidly and are expected to continue to increase in importance in the future. While non-embedded chips are fairly standardized and tend to be used in computers, embedded chips tend to be highly diverse and are used in a wide array of applications. As shown in column 3 of table 3, this small, but growing, segment matters: price change for embedded MPUs is substantially slower than that of Intel's chips. And, as shown in column 4, a Fisher of the two types of chips falls perceptively slower than the ACD measure of Intel's prices.

To obtain an index for this MOS micro and logic segment as a whole, the two MPU measures were combined with seven other indexes that were constructed for devices that, taken together, make up about $2 / 3$ of the non-MPU portion of the segment: microcontrollers, digital signal processors, general purpose logic, gate arrays, standard cell chips, and field programmable logic. As detailed in the appendix, the data for these devices were scarce and required some assumptions to fill in the gaps: in some cases, because nominal shipments data were not available, the best one could do is to construct geometric means. In other cases, data to construct Fisher indexes were available but only for some of the years. Care was taken to ensure that the assumptions made to fill in the gaps would err on the side of understating price declines in the aggregate indexes.

The resulting price index is compared to the PPI in chart 2. As was the case with memory devices, the producer price index for this segment shows very small price declines when compared with the new indexes. As seen below, the gap arises in the indexes for "other logic"; the price measures for microprocessors are quite comparable. 


\section{OTHER DEVICES}

Indexes were also constructed for devices outside of MOS memory and logic. In 1999, these devices, taken together, made up 18 and 15 percent of the world and US markets, in nominal terms. Most of these devices are old, established electronic equipment-like transistors - that are not undergoing a lot of technical change. One exception is analog chips-chips that are heavily used in the production of communications equipment.

The indexes for these devices are chained Fisher indexes that were constructed using the relatively aggregated average sales price and unit data from Semiconductor Industries Association (SIA). There are two things to note about the measured price change for these devices. As shown in chart 3, measured price change for "other integrated circuits rarely fall more than 15 percent-slow price declines when compared with those of other devices. Second, the new price index shows, on balance, slower price declines than either the xxxxxx corresponding PPI.

Although it is hard to tell without higher-quality data, it is probably the case that both the new and PPI indexes have limitations that will tend to understate price declines for these devices. For the new indexes constructed using the SIA data, it is probably safe to say that the data are not sufficiently disaggregated to adequately control for quality changes. Because raw prices typically rise as quality improves, if one doesn't adequately control for quality improvements the price declines in an index will be damped by quality-related price increases. That is, prices probably fall faster than these new indexes show.

In contrast, although the quality of devices are very precisely determined and tracked in the PPI, the use of Laspeyres weights in that index will, all else held equal, yield price declines that are understated. Aggregate prices probably fall faster than these indexes as well. 


\section{SUMMARY}

This paper provides highly disaggregate measures for semiconductor devices. As is well known, differences in the assumptions used to form aggregate indexes will have a non-trivial impact on the numerical values of the resulting measures. As shown above, this is also true for semiconductor chips. The availability of these data should facilitate the construction of alternative price indexes by other researchers. 


\section{APPENDIX}

\section{Construction of Price IndeXes}

Most of the price indexes used to measure price change for semiconductor devices are matched-model, chain-type Fisher indexes of aggregate price change. In a few cases where quantity data were not available, however, it was necessary to construct geometric means.

\section{Matched-Model chained Fisher Indexes}

For two adjacent periods, if all goods sold at time $\mathrm{t}$ were also sold at time $\mathrm{t}-1$, then a Fisher Index number $\left(\mathbf{P}_{t, t-1}\right)$ that measures aggregate price change from $t-1$ to $t$ is given by:

$$
\mathrm{P}_{\mathrm{t}, \mathrm{t}-1}^{\mathrm{F}}=\left[\Sigma_{\mathrm{m}} \omega_{\mathrm{m}, \mathrm{t}-1}\left(\mathrm{P}_{\mathrm{m}, \mathrm{t}} / \mathrm{P}_{\mathrm{m}, \mathrm{t}-1}\right) / \Sigma_{\mathrm{m}} \omega_{\mathrm{m}, \mathrm{t}}\left(\mathrm{P}_{\mathrm{m}, \mathrm{t}-1} / \mathrm{P}_{\mathrm{m}, \mathrm{t}}\right)\right]^{1 / 2} \quad, \quad \mathrm{~m}=1, \ldots
$$
$\mathrm{N}$

where the w's are nominal weights

$$
\omega_{\mathrm{m}, \mathrm{s}}=\mathrm{P}_{\mathrm{m}, \mathrm{s}} \mathrm{Q}_{\mathrm{m}, \mathrm{s}} / \Sigma_{\mathrm{m}}\left(\mathrm{P}_{\mathrm{m}, \mathrm{s}} \mathrm{Q}_{\mathrm{m}, \mathrm{s}}\right)
$$

and the notation $\Sigma_{\mathrm{m}}$ refers to summations taken over the matched models- the goods "alive" in both periods. To calculate a matched-model Fisher in the presence of births or deaths, one only includes prices in the index for goods that were alive in both periods. In general, one might be concerned that ignoring new and exiting goods might impart biases on the price index. However, if one has access to high frequency data that measures prices and quantities for technologically distinct products, then the bias from ignoring product turnover is minimized and hedonic techniques provide little or no advantage over the matched model techniques. ${ }^{3}$ This is because the weight on the unobserved price decline is likely very small in the first month or quarter of introduction.

3 Griliches, Triplett and others have noted that if one has the ideal data set, hedonic techniques do not provide an advantage over matched-model price index techniques. This same point was made in Aizcorbe, Corrado, and Doms (2000) and Silver and Heravi (2000). 
While the index formula in (1) measures price change over two adjacent periods (i.e., $t$ and $t-1$ ), price change over longer periods of time are measured by multiplying (chaining) these indexes together. Formally, to measure price change from some base period o to time $t$, the Fisher indexes for all the adjacent periods from o to $t$ are multiplied together:

(2) $\quad \mathrm{P}_{\mathrm{o}, \mathrm{t}-1}^{*}=\prod_{\mathrm{s}=\mathrm{o}, \mathrm{t}} \mathrm{P}_{\mathrm{o}, \mathrm{s}}^{\mathrm{F}}$

This method was used to calculate a price index for all semiconductor products and for three classes of semiconductor chips that make up integrated circuits: memory chips, logic chips, and other integrated circuits.

\section{Matched Model Geometric Means}

The formula for a geometric mean of price change from period $t-1$ to $t$ is given by:

$$
\mathrm{P}_{\mathrm{t}-1, \mathrm{t}}^{\mathrm{G}}=\Pi_{\mathrm{m}}\left(\mathrm{P}_{\mathrm{m}, \mathrm{t}} / \mathrm{P}_{\mathrm{m}, \mathrm{t}-1}\right)^{(1 / \mathrm{m})}
$$

where the notation $\Pi_{m}$ refers to products taken over goods that existed in both periods (goods denoted by $\mathrm{m}$ ). This index of price change over two adjacent periods are chained to obtain price change over longer periods of time:

$$
\mathrm{P}^{*}{ }_{0, t-1}=\prod_{s=0, t} P_{o, s}^{\mathrm{G}}
$$

\section{Data for Price SubindeXes}

Highly detailed data were obtained to construct matched model indexes for most devices classified in the semiconductor industry (SIC 3674). In table A1, the individual product classes itemized in the 1998 Current Industrial Reports (CIR) are listed along with information on whether data were available for the product class, and, if so, on the data source. Descriptions for each of these devices are available on the Semiconductor Industries Association web page at www.semichips.org. 
The CIR hierarchy was used as a backbone to facilitate the construction of indexes that use US shipments. Data were available for most product classes: the exceptions were small and were mostly devices outside of "Integrated Circuits"- the type of semiconductors typically measured in previous studies.

The collection of devices in integrated circuits may be thought of in three different classes: MOS memory, MOS logic and microcomponents, and other integrated circuits. In all cases, the data used to construct the sub-indexes were data for the world marketdata for US production are not available at the needed level of detail. Because semiconductor markets are highly global, it is probably safe to assume that prices for individual chips do not vary by country. However, to the extent that the distribution of production in the US differs from that in the world as a whole, these price indexes may not provide a precise representation of prices for the US market.

We discuss the data sources and the resulting price measure for each of these in turn.

\section{A. MOS MEMORY}

As may be seen in table Al data for the MOS memory indexes (lines 8-24) were obtained from Dataquest, Inc. Dataquest is an international organization that is one of the premier sources of data for high technology goods. Dataquest monitors unit shipments and prices charged by selected companies-making up over 90 percent of the market--at monthly or quarterly frequencies. These data on quarterly prices and quantities are proprietary and reported for 212 distinct devices produced between 1992 and 1999 and are essentially chip-level data. ${ }^{4}$ One potential drawback of the data is that they cover only contracted transactions, and do not capture spot market transactions. Tables A2 and A3 contain quarterly price indexes and world shipments for five types of MOS memory chips: DRAM, SRAM, EEPROM, EPROM, and Flash\&ROM. The devices differ by read-write capabilities and the technology used for their production.

4 The index constructed by Bruce Grimm was based on very similar data from DQ and used matched-model techniques. The main difference is that the Grimm data were annual while those used here are quarterly. Surprisingly, the frequency of the data does not appear to make much of a difference. 


\section{B. Mos LOGIC AND MiCROCOMPONENTS Microprocessors}

The construction of a price index for microprocessors (MPUs-shown in lines 2527 in table A1) required data from several sources. A chained-Fisher price index for nonembedded microprocessors was obtained from ACD (2000). That index-shown in the first column of table A4-is based on data obtained from MicroDesignResources (MDR). The MDR data provide prices and quantities for 43 technologically distinct microprocessors produced by Intel - the dominant firm in the non-embedded market throughout the 1990s. Intel's chips are produced mostly in the US and represented about $80 \%$ of the total value of microprocessors produced in the world in 1999.

Columns 2 and 3 provide the nominal value of shipments of Intel's MPUs-as estimated by MDR — and of embedded chips—estimated by multiplying the SIA WSTS nominal value of all MPUs with the SIA Microprocessor Report's estimate for the share of these shipments made up of embedded MPUs.

The data for the embedded microprocessors price index —obtained from DQ-are annual price data that begin in 1996. Because neither nominal shipments nor unit data were available at a sufficient level of detail, geometric means were constructed.

The two price indexes were then combined using nominal world shipments data for embedded and non-embedded microprocessors from Semiconductor Industries Association (SIA) to yield the overall MPU index on table 3 of the text.

\section{Other Microcomponents}

Although the microcomponent segment is one of the most dynamic in semiconductor markets, the segment has been largely neglected by statistical agencies and data vendors; these chips are all lumped together with other logic chips as "Other Logic" in the CIRs (line 28), and highly disaggregate data from private vendors is relatively scant. Because the price declines associated with individual chips in this product class are reportedly comparable to those associated with MOS memory and MPU chips, it is 
very important to use disaggregate data to identify the individual price contours for each chip.

The top panel of table A5 gives information on the sources and construction of indexes for these devices - the corresponding indexes are given in the bottom panel. The source data, and, hence, the indexes are all annual frequencies.

To construct price measures for both types of microcontrollers (MCUs and DSPs), annual data for the period 1996-99 were obtained from DQ and were used to calculate chained Fisher indexes. A measure for Microperipherals (MPRs) could not be constructed owing to lack of data (even SIA does not publish data for these devices).

\section{MOS Logic}

The scarcity of data for devices in the MOS Logic category does not allow construction of chained Fisher indexes using highly detailed data-the preferred method. Instead, price change for these devices was measured using matched-model geometric means, indexes that can control for quality change if the data are sufficiently disaggregate but do not use the proper (Fisher) weights.

For two types of MOS logic--general purpose logic and gate arrays-Dataquest publishes disaggregate price data that were used to construct geometric means for the period 1990-1999. For field programmable and standard cell logic devices, the DQ data was discontinued in 1994 and 1995, respectively, and SIA data are not available. The indexes and corresponding worldwide nominal shipments are given in table A6.

\section{Filling in the Gaps for Comparisons}

For most devices, when gaps arose, the only available data were the relativelyaggregate SIA data. These monthly-frequency data are slightly more aggregated over products; rather than reporting chip-level data, SIA reports average sales prices and shipments for chips grouped by common attributes. Because these data likely do not hold quality constant, and yield Fisher indexes that likely understate price declines, an alternative measure was constructed: a Fisher index of MOS memories, MPU and MCUs 
(denoted MMM). The advice of industry analysts about the relative pace of technical change for these devices guided both the construction of the MMM index and the choice of which index to use to measure price change for logic devices-SIA vs. MMM.

Price change for embedded MPUs from 1992-95 was measured using the ACD Fisher index for Intel's MPUs and that of MCUs and DSPs was measured using Fisher indexes based on the SIA data - on the latter, the price change as measured in the SIA data appear reasonable. Price change for the remaining devices-except "other special purpose logic"-was measured using the MMM index. Because data were simply not available, the category for "Other Special Purpose Logic" was simply excluded; this amounts to assuming that overall price change for devices in this category can be represented by an index of price change for all the other devices in the Micro/Other logic category.

\section{C. Other Devices}

Price change for the remaining devices was measured using chained Fisher indexes that were constructed using the relatively-aggregate average sales price and unit data from Semiconductor Industries Association (SIA). All told, we use observations for 84 such aggregates from the SIA data to form price indexes for most of the other devices listed in table 1 . The monthly indexes are given in table A7.

\section{Nominal Weights for Aggregation}

Aggregating from the sub-indexes discussed above to more aggregate indexes requires nominal shipments data. The very disaggregate shipments data are only available for world markets_-not US - and are given alongside the price indexes in the appendix tables. Normally, the source for the nominal shipments is the same as the source for the price data. At higher levels of aggregation, SIA data on the dollar value of world shipments are available. The shipments data for the nine coarse classes of integrated circuits and three classes of other semiconductors are given in table A8. 
Data on nominal US shipments are available from the Current Industrial Reports published by the Census Bureau. There are two potential problems in using these data. First, the global nature of the production process for semiconductor chips makes the value-added for these devices difficult to track. So, for example, the initial assembly of a chip might begin in a US fabrication facility (fab). After the chip is produced, it might be sent to Asia, where the labor-intensive testing and packaging occurs. The measurement problem is that it is not clear exactly what is meant by "US shipments" of these devicesdoes it include the value-added in Asia? The assumption necessary to use these data for weights is that the index is for finished chips and that the reported shipments data include all of the value of the chip. The second problem is that the published data cannot be used without some imputations and judgment calls because the data are often suppressed to avoid violating firms' confidentiality. The public data are available in computer-readable form from the Census Bureau web page at:http:/www.census.gov/cir/www/ma36q.html. 


\section{REFERENCES}

Aizcorbe, A.M. (1999) "Data Sources and Methods for the 136740 Benchmark Deflator", memorandum. .

Aizcorbe, A.M., C. Corrado and M. Doms (2000) "Constructing Price and Quantity Indexes for High Technology Goods”, paper presented at the NBER Summer Institute 2000, session on Price, Output and Productivity Measurement. Cambridge, MA, July 31.

Alterman, W. (1997) "A Comparison of the Export and Producer Price Indexes for Semiconductors", presented in the Workshop on Price Index Measurement at the NBER Summer Institute.

Berndt, E.R. and Z. Griliches (1993) "Measurement of DRAM Prices: Technology and Market Structure” in M.F. Foss, M.E.Manser, and A.H.Young, eds., Price Measurements and Their Uses, National Bureau of Economic Research.

Cole, Rosanne, Y.C. Chen, J. A. Barquin-Stolleman, E. Dulberger, N. Helvacian, J. Hodge,(1986) "Quality-Adjusted Price Indexes for Computer Processors and Selected Peripheral Equipment, Survey of Current Business 66(January):41-50.

Diewert, W.E. (2000) "Notes on Producing an Annual Superlative Index Using Monthly Price Data,” Discussion Paper No. 00-08, University of British Columbia.

Dulberger, E. R. (1989) "The Application of a Hedonic Model to a Quality-Adjusted Price Index for Computer Processors," in D.W. Jorgenson and R. Landau, eds., Technology and Capital Formation, Cambridge, Mass: MIT Press, Pp. 37-75.

Dulberger, E.R., (1993) "Sources of Price Decline in Computer Processors: Selected Electronic Components" in M.F. Foss, M.E.Manser, and A.H.Young, eds., Price Measurements and Their Uses, National Bureau of Economic Research.

Flamm, K (1993) "Measurement of DRAM Prices: Technology and Market Structure" in M.F. Foss, M. E. Manser, and A.H.Young, eds. Price Measurements and Their Uses, Cambridge, Mass.: National Bureau of Economic Research.

Flamm, K (1996) "Mismanaged Trade? Strategic Policy and the Semiconductor Industry," Washington, DC: Brookings Institution.

Flamm, K (1997) "More for Less: The Economic Impact of Semiconductors:, Semiconductor Industries Association.

Grimm, B.T. (1998) "Price Indexes for Selected Semiconductors, 1974-96," Survey of Current Business 78(February):8-24. 
Holdway, M. (1997) "An Alternative Methodology: Valuing Quality Change for Microprocessors in the PPI", mimeo, Bureau of Labor Statistics.

Holdway, M. (1998) "Measuring Price Change for Semiconductors in the Producer Price Index," mimeo, Bureau of Labor Statistics.

Silver, M and S. Heravi (2001) "Scanner Data and the Measurement of Inflation", Economic Journal, June.

Triplett, J. E. (1986) "The Economic Interpretation of Hedonic Methods," Survey of Current Business 66(January):36-40 
Table 1. Price Indexes for Semiconductors

\begin{tabular}{lrrr} 
& 1997 & 1998 & 1999 \\
\hline New & -42.9 & -53.5 & -47.7 \\
BEA & -24.25 & -37.3 & - \\
PPI & -9.6 & -8.1 & -4.2 \\
\hline
\end{tabular}

Sources: Authors' calculations based on proprietary

data, the price deflator used in BEA's GDP-by

industry program, and the BLS PPI for semiconductors. 
Table 2. Price Indexes for MOS Memory Chips (percent change)

\begin{tabular}{|c|c|c|c|c|c|c|c|c|}
\hline & 1992 & 1993 & 1994 & 1995 & 1996 & 1997 & 1998 & 1999 \\
\hline \multicolumn{9}{|l|}{ MOS Memory } \\
\hline New & - & -2.1 & 3.0 & -6.1 & -41.6 & -49.7 & -53.9 & -17.5 \\
\hline Grimm & -22.4 & -6.4 & 0.3 & -7.6 & -46.0 & & & \\
\hline \multicolumn{9}{|l|}{ DRAM } \\
\hline New & -29.8 & 1.6 & 2.1 & -1.5 & -57.2 & -64.0 & -65.1 & -15.7 \\
\hline Grimm & -29.5 & -1.5 & 2.2 & -2.6 & -59.4 & & & \\
\hline \multicolumn{9}{|l|}{ EEPROM } \\
\hline New & -19.8 & -8.8 & -20.9 & -17.2 & 2.3 & -44.1 & 39.3 & -62.4 \\
\hline Grimm & -18.7 & -8.2 & -19.7 & -16.2 & -4.2 & & & \\
\hline \multicolumn{9}{|l|}{ EPROM } \\
\hline New & -12.3 & -12.9 & 0.8 & -16.9 & -1.4 & -33.1 & -28.6 & -19.1 \\
\hline Grimm & -11.2 & -12.1 & 0.7 & -16.9 & 3.4 & & & \\
\hline \multicolumn{9}{|c|}{ Flash and ROM } \\
\hline New & -11.0 & -19.2 & -6.2 & -20.0 & -12.2 & -9.1 & -63.6 & -17.3 \\
\hline Grimm & -16.8 & -12.3 & -28.3 & -39.9 & -32.0 & & & \\
\hline \multicolumn{9}{|l|}{ SRAM } \\
\hline New & -17.4 & -9.1 & 10.0 & -10.1 & -33.1 & -35.3 & -35.0 & -11.7 \\
\hline Grimm & $(-29.4,-9.1)$ & $3.6,2.7)$ & $(-6.3,-2.0)$ & $(-36.0,19.0)($ & $3,-15.5)$ & & & \\
\hline
\end{tabular}

Sources: Authors' calculations based on proprietary data and Grimm(1998).

Note: Figures are percent changes for annual averages. 
Table 3. Price Indexes for Microprocessors

\begin{tabular}{llllll}
\hline & \multicolumn{2}{l}{ Non-Embedded } & & \\
\cline { 2 - 3 } & Grimm & ACD & & Embedded & Total \\
\hline 1993 & -30.0 & & & \\
1994 & -37.1 & -31.6 & & \\
1995 & -65.9 & -58.6 & & \\
1996 & -60.0 & -60.8 & & -52.1 \\
1997 & & -53.2 & & -39.6 & -63.8 \\
1998 & & -67.3 & & -8.9 & -57.4 \\
1999 & & -61.7 & 15.3 &
\end{tabular}


Table A1. Data Sources and Coverage

\begin{tabular}{|c|c|c|c|c|c|c|c|}
\hline & & & & & DATA & SOUR & \\
\hline & Product Description & & & $\overline{\mathrm{DQ}}$ & MDR & SIA & No data \\
\hline 1 & IC gallium arsendide & Memory & & & & & \\
\hline 2 & & Logic and oth & & & & & \\
\hline 3 & Bipolar memory & (SRAM)... & & & & & \\
\hline 4 & & XSRAM & & & & & \\
\hline 5 & Bipolar transistors & Transistor-tra & sistor logic (TTL). & & & & \\
\hline 6 & & Emitter coup & logic (ECL) & & & & \\
\hline 7 & & $x E C L, x T T L$ & & & & & \\
\hline 8 & MOS memory & DRAM & Not over 80K. & & & & \\
\hline 9 & & DRAM & Over $80 \mathrm{k}$ but not over $300 \mathrm{k}$. & & & & \\
\hline 10 & & DRAM & Over $300 \mathrm{k}$ but not over $3 \mathrm{MB}$. & & & & \\
\hline 11 & & DRAM & Over $3 \mathrm{MB}$ but not over $15 \mathrm{MB}$ & & & & \\
\hline 12 & & DRAM & Over $15 \mathrm{MB} \ldots$ & & & & \\
\hline 13 & & SRAM & Not over $40 \mathrm{~K}$ & & & & \\
\hline 14 & & SRAM & Over $40 \mathrm{~K}$ but not over $80 \mathrm{~K}$. & & & & \\
\hline 15 & & SRAM & Over $80 \mathrm{~K}$ but not over $300 \mathrm{~K}$. & & & & \\
\hline 16 & & SRAM & Over $300 \mathrm{~K}$ but not over $3 \mathrm{MB}$ & & & & \\
\hline 17 & & SRAM & Over 3MB..... & $E$ & & & \\
\hline 18 & & EEPROMS & Not over 8oK. & 柴: & & & \\
\hline 19 & & EEPROMS & Over $80 \mathrm{~K}$ but not over $900 \mathrm{~K}$ & $=$ & & & \\
\hline 20 & & EEPROMS & Over $900 \mathrm{~K} . .$. & & & & \\
\hline 21 & & EPROMS & Not over $80 \mathrm{~K}$ & 部. & & & \\
\hline 22 & & EPROMS & Over $80 \mathrm{~K}$ but not over $900 \mathrm{~K}$. & & & & \\
\hline 23 & & EPROMS & Over $900 \mathrm{~K} \ldots$ & & & & \\
\hline 24 & & Other nonvol & tinec & & & & \\
\hline 25 & MOS logic & MPUs havin & an internal data bus of 8 bits or less. & & $A C D$ & & \\
\hline 26 & & MPUs having & an internal data bus of 16 bits. & & $A C D$ & & \\
\hline 27 & & MPUs having & an internal data bus of 32 bits or more & & $A C D$ & & \\
\hline 28 & & Other (micro & ontrollers, ASICs, PLAs, etc.)..... & & & & \\
\hline 29 & other & Complement & ry BiMOS (BiCMOS)...... & & & & \\
\hline 30 & & Other compl & nentary BiMOS(BiCMOS), including logic ... & & & & \\
\hline 31 & & Other digita: & licon $1 \mathrm{Cs}$.. & & & & \\
\hline 32 & analog & Radio freque & cy..... & & & & \\
\hline 33 & & Other, analo & & & & & \\
\hline 34 & & Other, includ & Ig mixed signal (analog/digital), logic . & & & & \\
\hline 35 & & Other, includ & Ig mixed signal (analog/digital), other.. & & & & \\
\hline 36 & hybrid & Radio freque & & & & & \\
\hline 37 & & Other... & & & & & \\
\hline 38 & IC & Other..... & & & & & \\
\hline 39 & Transistors...... & Signal (less & an 1 watt dissipation) & & & & \\
\hline 40 & & Power (1 wa & or greater dissipation) & & & & \\
\hline 41 & Diodes and rectifiers... & le .5 amps & & & & & \\
\hline 42 & & gt.5amps & & & & & \\
\hline 43 & & Zener diode: & & & & & \\
\hline 44 & & Selenium re & fiers.... & & & & \\
\hline 45 & & Microwave d & des & & & & \\
\hline 46 & Light-emitting diodes & Solar cells... & & & & & \\
\hline 47 & & Discrete, inf & red and laser..... & & & & \\
\hline 48 & & Alpha or nur & eric displays. & & & & \\
\hline 49 & & Photodiodes & including infrared detectors. & & & & \\
\hline 50 & & Optical coup & disolators, including sensors and emitters...... & & & & \\
\hline 51 & & Other light s & isitive and light-emitting devices & & & & \\
\hline 52 & Thyristors & & & & & & \\
\hline 53 & Hall effect devices.. & & & & & & \\
\hline 54 & All other semiconducto & $r$ devices & & & & & \\
\hline 55 & Semiconductor parts: & Chips and $w$ & For integrated circuits (IC's)... & & & & 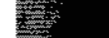 \\
\hline 56 & & Chips and w & For discrete semiconductors...... & & & & \\
\hline 57 & & All other sen & conductor parts & & & & \\
\hline
\end{tabular}

Note: Data sources are denoted as follows: Dataquest, Inc. (DQ), MicroDesign Resources (MDR), Semiconductor Industries Association (SIA), Aizeorbe, Corrado and Doms (ACD). 
Table A2. Price Indexes for MOS Memory Devices

\begin{tabular}{|c|c|c|c|c|c|}
\hline & DRAM & SRAM & EEPROM & EPROM & Flash \& ROM \\
\hline $90 q 4$ & 1.00000 & 1.00000 & 1.00000 & 1.00000 & 1.00000 \\
\hline $91 q 1$ & 0.90454 & 1.27977 & 0.86309 & 1.07021 & 0.87747 \\
\hline $91 q 2$ & 0.86970 & 0.99324 & 0.78711 & 1.01097 & 0.83481 \\
\hline $91 q^{3}$ & 0.79076 & 0.97790 & 0.72742 & 0.95661 & 0.80459 \\
\hline $91 q 4$ & 0.71292 & 0.89898 & 0.67095 & 0.88462 & 0.77312 \\
\hline $92 q 1$ & 0.64331 & 0.86549 & 0.65562 & 0.93481 & 0.83244 \\
\hline $92 q 2$ & 0.57623 & 0.85774 & 0.62700 & 0.86130 & 0.76592 \\
\hline $92 q 3$ & 0.54328 & 0.84742 & 0.59484 & 0.83307 & 0.69829 \\
\hline $92 q 4$ & 0.53672 & 0.85848 & 0.56807 & 0.80986 & 0.63116 \\
\hline $93 q^{1}$ & 0.56565 & 0.78027 & 0.59331 & 0.73551 & 0.61024 \\
\hline $93 q 2$ & 0.57869 & 0.76316 & 0.56853 & 0.74051 & 0.59702 \\
\hline $93 q 3$ & 0.58410 & 0.77220 & 0.54057 & 0.75440 & 0.58679 \\
\hline $93 q 4$ & 0.60846 & 0.80001 & 0.52708 & 0.76529 & 0.57241 \\
\hline $94 q 1$ & 0.62013 & 0.85038 & 0.45824 & 0.77880 & 0.59667 \\
\hline $94 q 2$ & 0.59909 & 0.87190 & 0.44917 & 0.76896 & 0.56673 \\
\hline $94 q^{3}$ & 0.58617 & 0.85180 & 0.43635 & 0.74136 & 0.53953 \\
\hline $94 q 4$ & 0.58072 & 0.85169 & 0.42008 & 0.73090 & 0.51649 \\
\hline $95 q^{1}$ & 0.58635 & 0.74758 & 0.38111 & 0.63772 & 0.47000 \\
\hline $95 q 2$ & 0.59570 & 0.75498 & 0.36968 & 0.62689 & 0.45572 \\
\hline $95 q^{3}$ & 0.60288 & 0.78507 & 0.35811 & 0.61476 & 0.42816 \\
\hline $95 q 4$ & 0.56550 & 0.79341 & 0.35098 & 0.62897 & 0.42177 \\
\hline $96 q 1$ & 0.43951 & 0.72044 & 0.42567 & 0.65056 & 0.46379 \\
\hline $96 q 2$ & 0.24080 & 0.55032 & 0.39267 & 0.63334 & 0.39910 \\
\hline $96 q 3$ & 0.17278 & 0.41731 & 0.35435 & 0.63150 & 0.35861 \\
\hline $96 q 4$ & 0.15308 & 0.37232 & 0.32064 & 0.55828 & 0.33679 \\
\hline $97 q 1$ & 0.11921 & 0.35484 & 0.22782 & 0.44260 & 0.40209 \\
\hline $97 q 2$ & 0.10318 & 0.33767 & 0.21402 & 0.41942 & 0.35328 \\
\hline $97 q 3$ & 0.07707 & 0.32408 & 0.20204 & 0.39700 & 0.33680 \\
\hline $97 q 4$ & 0.06261 & 0.31658 & 0.19095 & 0.39601 & 0.32478 \\
\hline $98 q 1$ & 0.04397 & 0.28819 & 0.30672 & 0.30934 & 0.15173 \\
\hline $98 q 2$ & 0.03173 & 0.22368 & 0.29444 & 0.29751 & 0.13563 \\
\hline $98 q 3$ & 0.02438 & 0.18676 & 0.28388 & 0.29001 & 0.11628 \\
\hline $98 q 4$ & 0.02635 & 0.16806 & 0.27750 & 0.28411 & 0.11256 \\
\hline $99 q 1$ & 0.02944 & 0.20599 & 0.11600 & 0.29738 & 0.09795 \\
\hline $99 q 2$ & 0.02397 & 0.19648 & 0.11200 & 0.25040 & 0.09492 \\
\hline $99 q 3$ & 0.02274 & 0.18663 & 0.10762 & 0.21741 & 0.11193 \\
\hline 9994 & 0.03040 & 0.17606 & 0.10121 & 0.19038 & 0.12230 \\
\hline
\end{tabular}

Source: Author's calculations based on proprietary data from DATAQUEST, Inc. 
Table A3. Worldwide Nominal Shipments of MOS Memory Devices (thousands of dollars)

\begin{tabular}{|c|c|c|c|c|c|}
\hline & & DRAM & SRAM & EPROM & OTHER \\
\hline $91 q$ & 1 & 1644725 & 596927 & 378601 & 328027 \\
\hline $91 \mathrm{q}$ & 2 & 1617883 & 604197 & 372471 & 379817 \\
\hline $91 q$ & 3 & 1672352 & 643032 & 336399 & 459999 \\
\hline $91 q$ & 4 & 1669989 & 644864 & 349036 & 534781 \\
\hline $92 q$ & 1 & 1949566 & 696622 & 292843 & 451364 \\
\hline $92 q$ & 2 & 2016150 & 714642 & 326468 & 482509 \\
\hline $92 q$ & 3 & 2199226 & 741738 & 316658 & 578184 \\
\hline $92 q$ & 4 & 2358005 & 737713 & 311754 & 661911 \\
\hline $93 q$ & 1 & 2587181 & 727060 & 304839 & 648092 \\
\hline $93 q$ & 2 & 3033703 & 837952 & 337744 & 779764 \\
\hline $93 q$ & 3 & 3567432 & 882950 & 353135 & 979120 \\
\hline $93 q$ & 4 & 3952027 & 847395 & 353882 & 1074591 \\
\hline $94 \mathrm{q}$ & 1 & 4431633 & 822165 & 373448 & 925429 \\
\hline $94 q$ & 2 & 5362752 & 882633 & 382392 & 879980 \\
\hline $94 q$ & 3 & 6276922 & 990620 & 323870 & 987375 \\
\hline $94 q$ & 4 & 7345981 & 1058872 & 308470 & 1097784 \\
\hline $95 q$ & 1 & 8014834 & 1224892 & 334643 & 1072318 \\
\hline $95 q$ & 2 & 9544862 & 1518808 & 380673 & 1141456 \\
\hline $95 q$ & 3 & 10805591 & 1555278 & 343454 & 1409723 \\
\hline $95 q$ & 4 & 12467465 & 1773845 & 326366 & 1543702 \\
\hline $96 q$ & 1 & 9968980 & 1506514 & 324589 & 1314932 \\
\hline $96 q$ & 2 & 5945874 & 1301360 & 335052 & 1180001 \\
\hline $96 q$ & 3 & 4570186 & 1009045 & 234884 & 1247309 \\
\hline $96 q$ & 4 & 4647148 & 928150 & 208452 & 1295735 \\
\hline $97 q$ & 1 & 4672817 & 793342 & 190516 & 1183455 \\
\hline $97 q$ & 2 & 5197474 & 893831 & 190802 & 1255868 \\
\hline $97 q$ & 3 & 5504164 & 1063065 & 182233 & 1237759 \\
\hline $97 q$ & 4 & 4423668 & 1092245 & 176747 & 1277109 \\
\hline $98 q$ & 1 & 3592660 & 1105640 & 153955 & 1118726 \\
\hline $98 q$ & 2 & 2850987 & 957372 & 136223 & 1096883 \\
\hline $98 q$ & 3 & 3250753 & 894800 & 109652 & 1062461 \\
\hline $98 q$ & 4 & 4316359 & 936678 & 122178 & 1287674 \\
\hline $99 q$ & 1 & 4676241 & 1063097 & 119165 & 1178048 \\
\hline $99 q$ & 2 & 4292581 & 1078161 & 120612 & 1378512 \\
\hline $99 q$ & 3 & 4914244 & 1163833 & 117718 & 1681730 \\
\hline $99 q$ & 4 & 6830781 & 1357074 & 129138 & 2185195 \\
\hline
\end{tabular}

Source: Author's calculations based on SIA's WSTS survey. 
Table A4. Price Index and Nominal Shipments for Microprocessors (thousands of dollars)

\begin{tabular}{lccr}
\hline & Intel & \multicolumn{2}{c}{ Worldwide Nominals } \\
\cline { 3 - 4 } & Price Index & Total & Embedded \\
\hline 93q1 & 1.0000 & $2,067,163$ & 116,629 \\
93q2 & 0.9620 & $2,116,777$ & 125,791 \\
93q3 & 0.9080 & $2,176,177$ & 153,216 \\
93q4 & 0.8100 & $2,229,569$ & 153,696 \\
94q1 & 0.7670 & $2,591,130$ & 173,502 \\
94q2 & 0.6900 & $2,667,331$ & 196,543 \\
94q3 & 0.5810 & $2,715,836$ & 191,454 \\
94q4 & 0.4860 & $3,021,189$ & 200,507 \\
95q1 & 0.3790 & $3,619,841$ & 255,592 \\
95q2 & 0.2940 & $3,528,236$ & 349,375 \\
95q3 & 0.2250 & $3,412,064$ & 373,525 \\
95q4 & 0.1750 & $3,718,451$ & 359,540 \\
96q1 & 0.1290 & $4,011,002$ & 416,669 \\
96q2 & 0.0986 & $3,881,352$ & 462,456 \\
96q3 & 0.0806 & $4,608,572$ & 379,410 \\
96q4 & 0.0765 & $6,029,070$ & 507,696 \\
97q1 & 0.0657 & $6,299,936$ & 473,183 \\
97q2 & 0.0512 & $5,680,634$ & 437,011 \\
97q3 & 0.0387 & $5,535,553$ & 502,201 \\
97q4 & 0.0302 & $5,950,806$ & 598,598 \\
98q1 & 0.0213 & $5,280,009$ & 397,315 \\
98q2 & 0.0156 & $5,449,305$ & 441,612 \\
98q3 & 0.0117 & $6,552,289$ & 528,012 \\
98q4 & 0.0098 & $7,494,042$ & 635,748 \\
99q1 & 0.0079 & $6,777,190$ & 465,266 \\
99q2 & 0.0061 & $5,902,013$ & 572,748 \\
99q3 & 0.0047 & $6,805,851$ & 586,976 \\
99q4 & 0.0038 & $7,706,351$ & 713,982 \\
\hline 50un & & &
\end{tabular}

Sources:

Index: Aizcorbe, Corrado and Doms (2000)--col (1), table 12 Worldwide nominals: obtained from SIA's WSTS survey Embedded: Author's calculation based on data from SIA (Shares from SIA's Microprocessor Report applied to WSTS revenues for MPUs) 
Table A5. Price Indexes Used for MOS Logic and Microcomponents

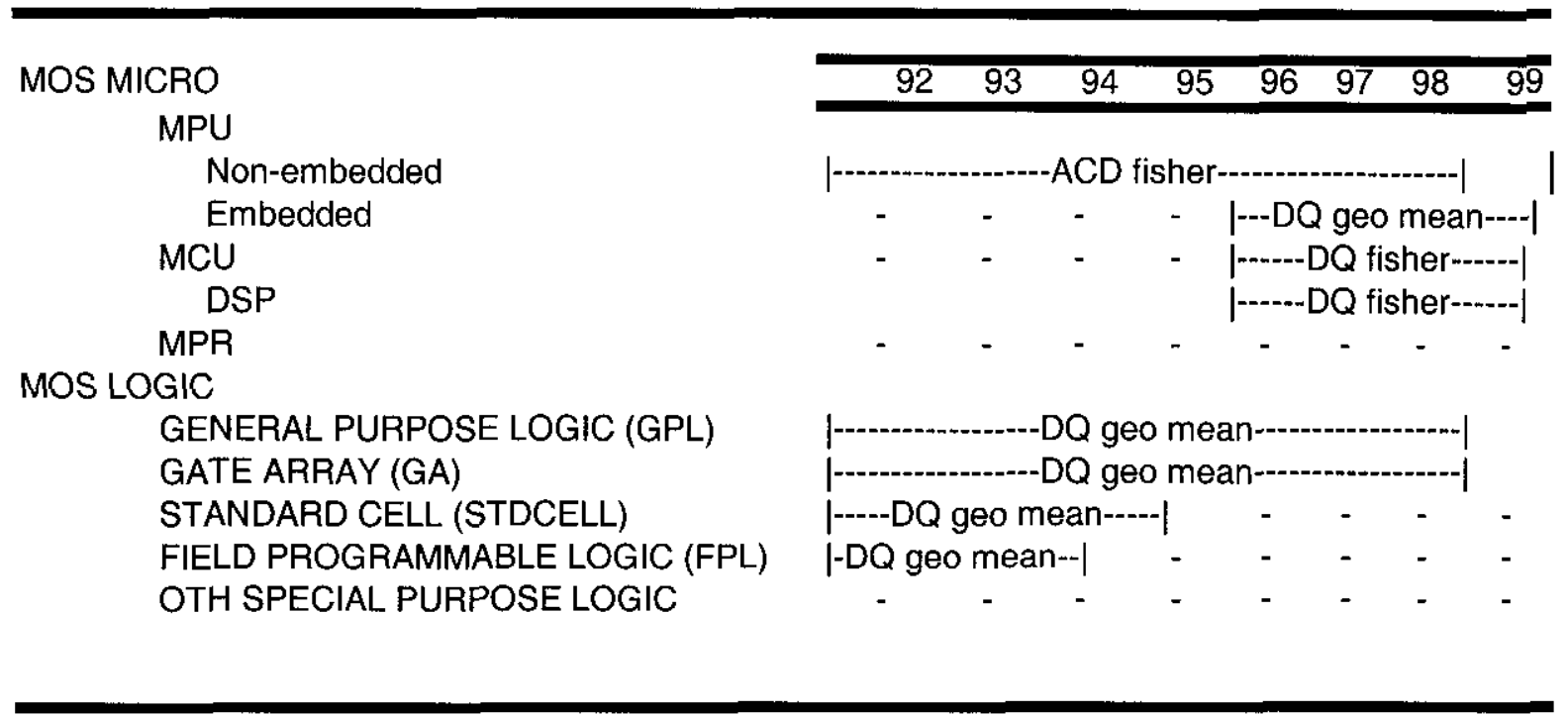


Table A6. MOS Microcomponents and Logic Chips

Annual Price Indexes and World Nominal Shipments, 1990-99

\begin{tabular}{|c|c|c|c|c|c|c|c|}
\hline \multicolumn{2}{|r|}{$\mathrm{MCU}$} & DSP & GPL & \multicolumn{2}{|c|}{ GA STDCELL } & FPL & OTHER \\
\hline \multicolumn{8}{|c|}{ Annual Price Deflators } \\
\hline 1990 & & & 1.0000 & 1.0000 & 1.0000 & 1.0000 & \\
\hline 1991 & & & 0.9763 & 0.8697 & 0.8473 & 0.9525 & \\
\hline 1992 & & & 0.9328 & 0.8160 & 0.7525 & 0.6764 & \\
\hline 1993 & & & 1.0178 & 0.7327 & 0.7970 & 0.5667 & \\
\hline 1994 & & & 1.3652 & 0.6575 & 0.6453 & 0.4730 & \\
\hline 1995 & & & 1.1903 & 0.6266 & 0.6021 & & \\
\hline 1996 & 1.0000 & 1.0000 & 1.0563 & 0.5326 & 0.5118 & & \\
\hline 1997 & 0.8370 & 0.8520 & 0.9292 & 0.4961 & 0.4778 & & \\
\hline 1998 & 0.6905 & 0.7458 & 0.8390 & 0.2607 & 0.3080 & & \\
\hline 1999 & 0.6035 & 0.7309 & 0.7602 & 0.2135 & 0.2540 & & \\
\hline \multicolumn{8}{|c|}{ Nominal World Shipments } \\
\hline 1991 & 4514639 & 337262 & 1120924 & 2457948 & 1485764 & 463433 & 3732286 \\
\hline 1992 & 4798589 & 446571 & 1075174 & 2540187 & 1311666 & 662455 & 3742311 \\
\hline 1993 & 5885742 & 674626 & 1439934 & 3117811 & 1610120 & 958851 & 4731000 \\
\hline 1994 & 7275709 & 1000675 & 1834927 & 3874187 & 2721695 & 1117529 & 5980724 \\
\hline 1995 & 9006893 & 1728902 & 2255708 & 4849436 & 3637455 & 1646591 & 7391844 \\
\hline 1996 & 9028803 & 2406635 & 1935779 & 4419165 & 4688959 & 1658372 & 5873549 \\
\hline 1997 & 9408496 & 3214407 & 2370346 & 3960484 & 6334082 & 2042644 & 6339915 \\
\hline 1998 & 8618673 & 3497151 & 1903682 & 3021871 & 5382377 & 2174336 & 6082147 \\
\hline 1999 & 9696421 & 4386769 & 2171104 & 2463899 & 7332577 & 2899540 & 8291347 \\
\hline
\end{tabular}

Source: Indexes: Author's calculations based on proprietary data from DATAQUEST.

Nominal World Shipments are SIA's WSTS shipments series. 
Title A7 Price Indexes for Other Integrated Circuits and Discrete Devices

Other Integrated Circuits

$$
\text { Bipolar }
$$

$\begin{array}{lrrr}\text { Jan } & 92 & 1.00000 & 1.00000 \\ \text { Feb } & 92 & 1.05495 & 0.97337 \\ \text { Mar } & 92 & 0.97011 & 0.99034 \\ \text { Apr } & 92 & 0.99034 & 0.92281 \\ \text { May } & 92 & 0.94738 & 0.96109 \\ \text { Jun } & 92 & 0.98724 & 1.00244 \\ \text { Jul } & 92 & 1.04713 & 0.99165 \\ \text { Aug } & 92 & 1.00737 & 1.01341 \\ \text { Sep } & 92 & 1.13236 & 1.07617 \\ \text { Oct } & 92 & 1.03261 & 1.08119 \\ \text { Nov } & 92 & 1.00281 & 1.03626 \\ \text { Dec } & 92 & 0.95200 & 1.07268 \\ \text { Jan } & 93 & 1.00196 & 1.08199 \\ \text { Feb } & 93 & 0.95908 & 1.02670 \\ \text { Mar } & 93 & 0.98323 & 1.08869 \\ \text { Apr } & 93 & 1.06346 & 1.09890 \\ \text { May } & 93 & 1.08126 & 1.05239 \\ \text { Jun } & 93 & 1.10058 & 1.11894 \\ \text { Jul } & 93 & 1.11570 & 1.07953 \\ \text { Aug } & 93 & 1.15082 & 1.08572 \\ \text { Sep } & 93 & 1.14975 & 1.09359 \\ \text { Oct } & 93 & 1.20928 & 1.12002 \\ \text { Nov } & 93 & 1.19269 & 1.07007 \\ \text { Dec } & 93 & 1.14395 & 1.08931 \\ \text { Jan } & 94 & 1.16727 & 1.10255 \\ \text { Feb } & 94 & 1.17341 & 1.10717 \\ \text { Mar } & 94 & 1.08670 & 1.15051 \\ \text { Apr } & 94 & 1.14634 & 1.16008 \\ \text { May } & 94 & 1.09138 & 1.13585 \\ \text { Jun } & 94 & 1.14728 & 1.14875 \\ \text { Jul } & 94 & 1.12434 & 1.18426 \\ \text { Aug } & 94 & 1.10781 & 1.16237 \\ \text { Sep } & 94 & 1.09729 & 1.21899 \\ \text { Oct } & 94 & 1.14349 & 1.22298 \\ \text { Nov } & 94 & 1.13206 & 1.20106 \\ \text { Dec } & 94 & 1.11060 & 1.21605 \\ \text { Jan } & 95 & 0.99807 & 1.21540 \\ \text { Feb } & 95 & 1.07518 & 1.17977 \\ \text { Mar } & 95 & 1.01758 & 1.24654 \\ \text { Apr } & 95 & 1.05958 & 1.29439 \\ \text { May } & 95 & 1.13071 & 1.26904 \\ \text { Jun } & 95 & 1.25339 & 1.28165 \\ \text { Jul } & 95 & 1.11126 & 1.28452 \\ \text { Aug } & 95 & 1.12525 & 1.20299 \\ \text { Sep } & 95 & 1.14202 & 1.22664 \\ \text { Dect } & 95 & 1.03539 & 1.26685 \\ & 95 & 1.01146 & 1.23645 \\ \text { Dec } & 95 & 1.08294 & 1.24044 \\ \text { Man } & & & \end{array}$

Discrete Devices

Small Trans. Power Trans Diodes/Recs

1.0000

1.00853

0.98080

0.96455

0.98170

1.01712

1.00401

1.01554

1.07834

1.04872

0.99203

1.01032

0.99896

1.00489

1.04187

1.04561

1.08575

1.09670

1.03525

1.06708

1.09016

1.05604

1.01185

1.04021

1.00815

1.01749

1.05084

1.02209

1.04698

1.07136

1.07926

1.08174

1.11989

1.08319

1.07846

1.07958

1.09602

1.06825

1.12111

1.16011

1.15837

1.11337

1.07550

0.99819

0.99519

1.04218

1.03195

1.05238
1.00000

1.01468

0.99351

0.97442

0.95826

0.97248

0.95376

0.94191

0.97668

0.95331

0.93361

0.94684

0.92911

0.92286

0.94882

0.97455

0.94566

0.97143

0.96936

0.97797

0.99392

0.98704

0.96048

0.97262

0.97383

1.02181

0.97819

0.96256

0.96086

0.98016

1.01426

1.00259

1.02066

1.04455

1.00934

0.98166

1.00078

1.00892

1.05591

1.10662

1.05029

1.08396

1.02299

0.98593

0.95519

0.96366

0.93959

0.92503
1.00000

0.88675

0.89003

0.86476

0.86933

0.87900

0.88855

0.89225

0.94887

0.95203

0.88486

0.87654

0.87266

0.87273

0.87427

0.90870

0.89887

0.90513

0.87903

0.89629

0.91278

0.92518

0.90378

0.90274

0.88755

0.90451

0.91394

0.91977

0.85272

0.91182

0.92101

0.90974

0.94267

0.93518

0.93438

0.93758

1.02593

1.02893

1.06207

1.10321

1.06105

1.08361

1.08434

0.98355

0.99782

0.99244

0.97001

1.05278
Opto-LEDs

1.00000

0.97885

0.93849

0.98140

0.95221

0.96279

1.00377

1.00764

1.07188

1.07839

1.06279

1.01656

1.03665

1.03516

1.05946

1.03747

0.98605

1.00220

0.98558

1.03859

1.03226

1.00503

1.01311

0.97192

0.98728

1.00372

1.05145

1.01689

1.01955

1.04370

1.03499

1.01526

1.00515

1.00539

1.00505

0.99969

1.01336

1.01760

1.05977

1.11100

1.10675

1.07499

1.08279

1.03065

1.05297

0.97894

0.99598

0.97586
Thyristors

1.00000

0.71093

0.63799

0.65624

0.64750

0.62889

0.66767

0.68618

0.66760

0.67659

0.66832

0.62504

0.63686

0.66564

0.68187

0.65933

0.67587

0.64459

0.68067

0.68171

0.78162

0.68317

0.70260

0.59634

0.65786

0.73800

0.64902

0.65725

0.63319

0.64008

0.73663

0.72678

0.81400

0.71057

0.69059

0.62384

0.65958

0.65816

0.63426

0.67607

0.66805

0.70975

0.63614

0.59631

0.58785

0.57269

0.61216

0.44491 
Title A7 Price Indexes for Other Integrated Circuits and Discrete Devices (cont.)

Other Integrated Circuits

\begin{tabular}{|c|c|c|c|c|c|c|c|c|}
\hline & \\
\hline & & Bipolar & Analog & Small Trans. & Power Trans & Diodes/Recs & Opto-LEDs & Thyristors \\
\hline & & - n..-- & -..-. & & -.....-- & ----------- & --.-- & \\
\hline Jan & 96 & 0.92372 & 1.26784 & 1.01557 & 0.93990 & 0.93559 & 0.99087 & 0.58017 \\
\hline $\mathrm{Feb}$ & 96 & 1.01897 & 1.23321 & 1.03528 & 0.88994 & 0.95650 & 0.99165 & 0.62619 \\
\hline Mar & 96 & 1.02567 & 1.29686 & 1.06934 & 0.88972 & 0.93791 & 0.98635 & 0.48753 \\
\hline Apr & 96 & 0.99790 & 1.33185 & 1.02589 & 0.85596 & 0.91671 & 1.00918 & 0.48833 \\
\hline May & 96 & 1.05356 & 1.25596 & 1.00226 & 0.88585 & 0.87621 & 0.99158 & 0.63399 \\
\hline Jun & 96 & 0.96129 & 1.32733 & 1.03812 & 0.87886 & 0.88568 & 0.97448 & 0.46909 \\
\hline Jul & 96 & 0.98798 & 1.29759 & 1.01227 & 0.88846 & 0.85729 & 0.94712 & 0.58040 \\
\hline Aug & 96 & 0.92718 & 1.24390 & 0.98745 & 0.83338 & 0.83093 & 0.90964 & 0.64368 \\
\hline Sep & 96 & 0.88931 & 1.28224 & 0.99075 & 0.82317 & 0.83704 & 0.93048 & 0.46779 \\
\hline Oct & 96 & 0.71720 & 1.31573 & 0.99910 & 0.80900 & 0.80860 & 0.88929 & 0.65669 \\
\hline Nov & 96 & 0.80846 & 1.23608 & 1.03701 & 0.78492 & 0.84810 & 0.90053 & 0.60771 \\
\hline Dec & 96 & 0.96109 & 1.24722 & 0.94567 & 0.78605 & 0.79244 & 0.86241 & 0.45676 \\
\hline Jan & 97 & 0.71999 & 1.29130 & 0.92195 & 0.78073 & 0.74724 & 0.85316 & 0.53956 \\
\hline Feb & 97 & 0.72426 & 1.20840 & 0.88380 & 0.75417 & 0.73893 & 0.76539 & 0.97728 \\
\hline Mar & 97 & 0.67966 & 1.20698 & 0.85928 & 0.73139 & 0.73678 & 0.77764 & 0.56056 \\
\hline Apr & 97 & 0.71670 & 1.25093 & 0.81390 & 0.71171 & 0.72276 & 0.73679 & 0.57301 \\
\hline May & 97 & 0.71847 & 1.20110 & 0.82122 & 0.72308 & 0.74128 & 0.74420 & 0.85632 \\
\hline Jun & 97 & 0.80476 & 1.20065 & 0.85531 & 0.71142 & 0.75975 & 0.76310 & 0.57251 \\
\hline Jul & 97 & 0.74080 & 1.16867 & 0.83380 & 0.70101 & 0.74188 & 0.77635 & 0.68601 \\
\hline Aug & 97 & 0.74455 & 1.12185 & 0.80894 & 0.70512 & 0.71782 & 0.75225 & 0.62733 \\
\hline Sep & 97 & 0.77712 & 1.17722 & 0.79351 & 0.71555 & 0.73321 & 0.77882 & 0.54098 \\
\hline Oct & 97 & 0.73624 & 1.20861 & 0.82487 & 0.70521 & 0.70099 & 0.71816 & 0.79346 \\
\hline Nov & 97 & 0.75697 & 1.13519 & 0.78406 & 0.67865 & 0.67382 & 0.70559 & 0.59996 \\
\hline Dec & 97 & 0.76948 & 1.15847 & 0.76501 & 0.67327 & 0.68982 & 0.71788 & 0.59387 \\
\hline Jan & 98 & 0.77535 & 1.17388 & 0.74255 & 0.66019 & 0.66311 & 0.71190 & 0.73338 \\
\hline Feb & 98 & 0.73028 & 1.08456 & 0.76628 & 0.65476 & 0.65949 & 0.71026 & 0.67817 \\
\hline Mar & 98 & 0.67727 & 1.13571 & 0.75323 & 0.63788 & 0.70365 & 0.71768 & 0.60164 \\
\hline Apr & 98 & 0.70003 & 1.17066 & 0.73064 & 0.65459 & 0.62092 & 0.69165 & 0.61521 \\
\hline May & 98 & 0.69938 & 1.08686 & 0.69968 & 0.66578 & 0.63287 & 0.68806 & 0.52972 \\
\hline Jun & 98 & 0.69229 & 1.08759 & 0.67465 & 0.65335 & 0.63547 & 0.69063 & 0.48334 \\
\hline Jul & 98 & 0.76640 & 1.09790 & 0.66165 & 0.67974 & 0.60889 & 0.69545 & 0.59139 \\
\hline Aug & 98 & 0.73081 & 1.03350 & 0.64891 & 0.62314 & 0.59910 & 0.65485 & 0.50921 \\
\hline Sep & 98 & 0.62886 & 1.08079 & 0.68699 & 0.62269 & 0.63232 & 0.67430 & 0.55737 \\
\hline Oct & 98 & 0.77114 & 1.11689 & 0.71430 & 0.66405 & 0.67223 & 0.75574 & 0.59186 \\
\hline Nov & 98 & 0.74169 & 1.05008 & 0.69919 & 0.60870 & 0.65861 & 0.73599 & 0.55969 \\
\hline Dec & 98 & 0.68570 & 1.11526 & 0.73028 & 0.62315 & 0.67674 & 0.72620 & 0.47665 \\
\hline Jan & 99 & 0.77701 & 1.08515 & 0.75480 & 0.63655 & 0.67055 & 0.72561 & 0.47713 \\
\hline Feb & 99 & 0.70499 & 1.03405 & 0.74058 & 0.67567 & 0.66292 & 0.70960 & 0.47736 \\
\hline Mar & 99 & 0.72604 & 1.05485 & 0.69943 & 0.67503 & 0.64119 & 0.69985 & 0.41321 \\
\hline Apr & 99 & 0.90258 & 1.04774 & 0.68240 & 0.64172 & 0.62115 & 0.67383 & 0.44424 \\
\hline May & 99 & 0.89238 & 1.04852 & 0.67943 & 0.65616 & 0.58613 & 0.63565 & 0.46097 \\
\hline Jun & 99 & 0.97066 & 1.07268 & 0.64899 & 0.64973 & 0.61070 & 0.66828 & 0.38455 \\
\hline Jul & 99 & 1.04170 & 1.05872 & 0.64865 & 0.63555 & 0.58357 & 0.62987 & 0.41292 \\
\hline Aug & 99 & 1.12788 & 1.05045 & 0.67668 & 0.63911 & 0.59451 & 0.64753 & 0.41517 \\
\hline Sep & 99 & 1.13965 & 1.09584 & 0.69349 & 0.66492 & 0.63512 & 0.68114 & 0.38511 \\
\hline Oct & 99 & 1.03753 & 1.08823 & 0.71106 & 0.65595 & 0.62076 & 0.67006 & 0.40564 \\
\hline Nov & 99 & 0.88370 & 1.06893 & $0.7 \uparrow 103$ & 0.63206 & 0.61081 & 0.69550 & 0.37701 \\
\hline Dec & 99 & 0.96389 & 1.10499 & 0.69220 & 0.65661 & 0.63553 & 0.74744 & 0.38226 \\
\hline
\end{tabular}

Source: Author's calculations based on proprietary data from Semiconductors industries Association 
Table A8. WSTS Worldwide Nominal Shipments for Semiconductor Devices (thousands of dollars)

\begin{tabular}{|c|c|c|c|c|c|c|c|c|c|c|c|}
\hline & \multicolumn{3}{|c|}{ MOS Memories } & \multicolumn{2}{|c|}{ MOS Micro/Logic } & \multirow[b]{2}{*}{ Analog } & \multirow[b]{2}{*}{ Sm. Trans. } & \multirow[b]{2}{*}{ Power Trans } & \multirow[b]{2}{*}{ Diodes/Recs } & \multirow[b]{2}{*}{ LEDs } & \multirow[b]{2}{*}{ Thyristors } \\
\hline & Bipolar & DRAM & MEMxDRAM & MPU & LogicxMPU & & & & & & \\
\hline $92 \mathrm{q} 1$ & 780779 & 1949566 & 1440829 & 1117277 & 4105243 & 2005724 & 426469 & 625752 & 593510 & 559222 & 134319 \\
\hline 92 q 2 & 780485 & 2016150 & 1523619 & 1083794 & 4321540 & 2149636 & 443986 & 644688 & 585216 & 552514 & 131375 \\
\hline 92 q 3 & 787745 & 2199226 & 1636580 & 1363164 & 4690261 & 2303512 & 470768 & 687591 & 616694 & 614189 & 134728 \\
\hline $92 q 4$ & 798440 & 2358005 & 1711378 & 1896024 & 4665148 & 2269815 & 442097 & 671788 & 589219 & 571453 & 126720 \\
\hline 93 q 1 & 766626 & 2587181 & 1679991 & 2067163 & 4782507 & 2312645 & 439668 & 685548 & 608409 & 573435 & 130520 \\
\hline 93 q 2 & 795672 & 3033703 & 1955460 & 2116777 & 5575626 & 2726191 & 505931 & 761328 & 670427 & 662255 & 146561 \\
\hline 93 q 3 & 813916 & 3567432 & 2215205 & 2176177 & 6036707 & 2840058 & 527645 & 797427 & 713364 & 724894 & 155746 \\
\hline $93 q 4$ & 773638 & 3952027 & 2275868 & 2229569 & 5944653 & 2794125 & 506704 & 771241 & 692238 & 693534 & 154394 \\
\hline 94 q 1 & 703483 & 4431633 & 2379946 & 2591130 & 6054821 & 2974677 & 520084 & 797412 & 708899 & 712699 & 163651 \\
\hline 94 q 2 & 727218 & 5362752 & 2432209 & 2667331 & 6916078 & 3403248 & 598422 & 921351 & 797282 & 804671 & 173698 \\
\hline 94 q 3 & 653139 & 6276922 & 2602900 & 2715836 & 7465219 & 3546455 & 651324 & 968684 & 833980 & 852549 & 184291 \\
\hline 94 q 4 & 689825 & 7345981 & 2752424 & 3021189 & 7917529 & 3660789 & 662735 & 1017461 & 874646 & 868468 & 185139 \\
\hline 95 q 1 & 636728 & 8014834 & 2928091 & 3619841 & 8497652 & 3811916 & 737967 & 1151696 & 957542 & 965644 & 191847 \\
\hline 95 q 2 & 765009 & 9544862 & 3369315 & 3528236 & 9966339 & 4392447 & 926551 & 1346619 & 1086498 & 1153978 & 219169 \\
\hline 95 q 3 & 712382 & 10805591 & 3654945 & 3412064 & 10055203 & 4309055 & 867781 & 1359169 & 1079498 & 1146573 & 210629 \\
\hline 95 q 4 & 659759 & 12467465 & 4015142 & $37 \uparrow 8451$ & 10379169 & 4132935 & 776720 & 1324084 & 1031256 & 1077366 & 185278 \\
\hline 96 q 1 & 542706 & 9968980 & 3424623 & 4011002 & 10097856 & 4112303 & 731743 & 1321475 & 1025579 & 1058177 & 192251 \\
\hline $96 q 2$ & 469282 & 5945874 & 3074815 & 3881352 & 10101117 & 4250916 & 701681 & 1306113 & 982626 & 1053034 & 185895 \\
\hline 96 q 3 & 452324 & 4570186 & 2758689 & 4608572 & 10346549 & 4218746 & 729284 & 1201378 & 931940 & 1029084 & 177261 \\
\hline $96 q 4$ & 461348 & 4647148 & 2713640 & 6029070 & 10877773 & 4461840 & 722162 & 1107102 & 934769 & 1006455 & 182371 \\
\hline $97 q^{1}$ & 414936 & 4672817 & 2455578 & 6299936 & 10874076 & 4388187 & 670669 & 1168838 & 926476 & 1013475 & 202598 \\
\hline 97 q 2 & 424059 & 5197474 & 2658291 & 5680634 & 11412864 & 4863964 & 704042 & 1285973 & 1000611 & 1104135 & 225347 \\
\hline 97 q 3 & 388650 & 5504164 & 2808223 & 5535553 & 11759069 & 5174105 & 716575 & 1331019 & 1023760 & 1227580 & 225941 \\
\hline $97 \mathrm{q} 4$ & 366374 & 4423668 & 2850718 & 5950806 & 11301285 & 5362683 & 665647 & 1297789 & 999219 & 1160739 & 251770 \\
\hline $98 \mathrm{q} 1$ & 338456 & 3592660 & 2457640 & 5280009 & 10536125 & 4940026 & 607527 & 1181246 & 962494 & 1161185 & 258525 \\
\hline 98 q 2 & 281161 & 2850987 & 2190478 & 5449305 & 9962080 & 4763431 & 596320 & 1133941 & 895458 & 1136880 & 215718 \\
\hline $98 \mathrm{q} 3$ & 230900 & 3250753 & 2066913 & 6552289 & 10059798 & 4576185 & 578923 & 1111481 & 847380 & 1127614 & 194452 \\
\hline 98 q 4 & 249195 & 4316359 & 2346530 & 7494042 & 10564448 & 4793313 & 591530 & 1190296 & 903968 & 1193764 & 174846 \\
\hline 99 q 1 & 209483 & 4676241 & 2360310 & 6777190 & 10024142 & 4767060 & 620115 & 1210163 & 890228 & 1236013 & 157814 \\
\hline $99 q 2$ & 244098 & 4292581 & 2577285 & 5902013 & 10606395 & 5125587 & 632800 & 1261647 & 952438 & 1308651 & 163600 \\
\hline 99 q 3 & 289179 & 4914244 & 2963281 & 6805851 & 11772374 & 5710442 & 705609 & 1403431 & 1026177 & 1544362 & 162583 \\
\hline $99 \mathrm{q} 4$ & 247540 & 6830781 & 3671407 & 7706351 & 12995978 & 6478612 & 794085 & 1528925 & 1146004 & 1688768 & 178029 \\
\hline
\end{tabular}

Source: Author's calculations based on SIA's WSTS shipments series 
Chart 1. Price Indexes for MOS Memory Chips

(Percent change, annual rate)

MOS Memories

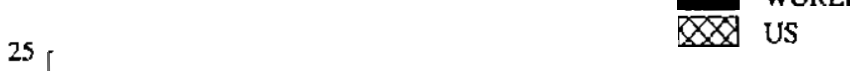

PPI

WORLD

20

15

10

5

0
-5
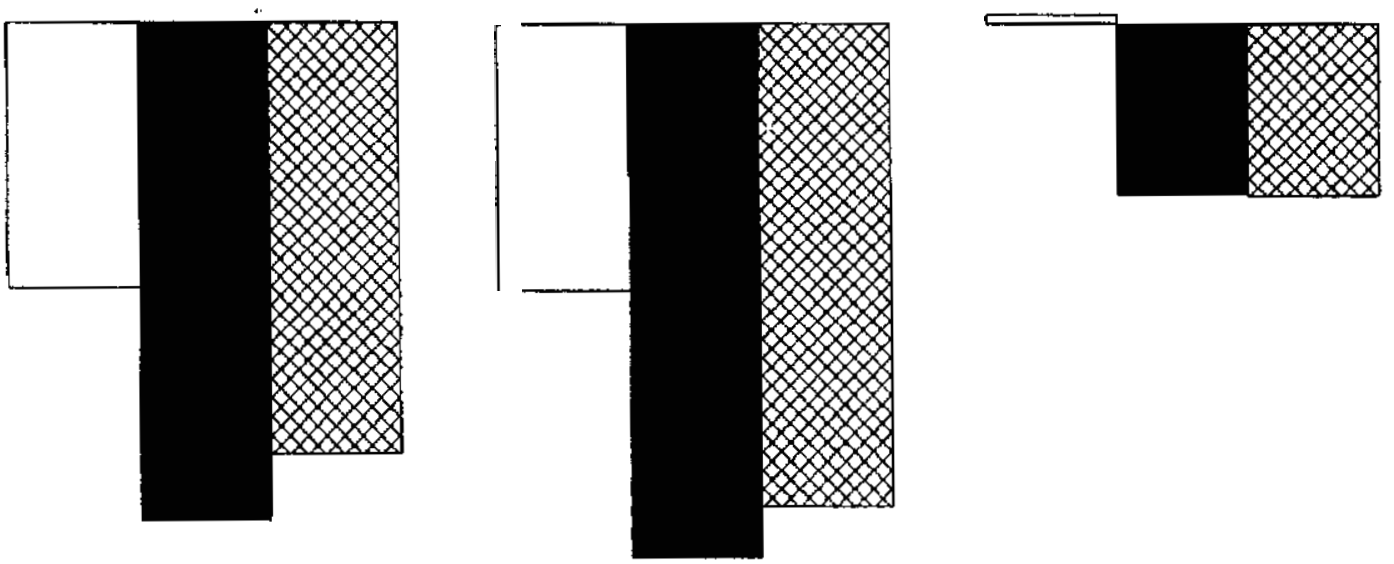

-10
-15

$-20$

$-25$

30

35

$-40$

$-50$

$-55$

$-60$

.65

DRAM

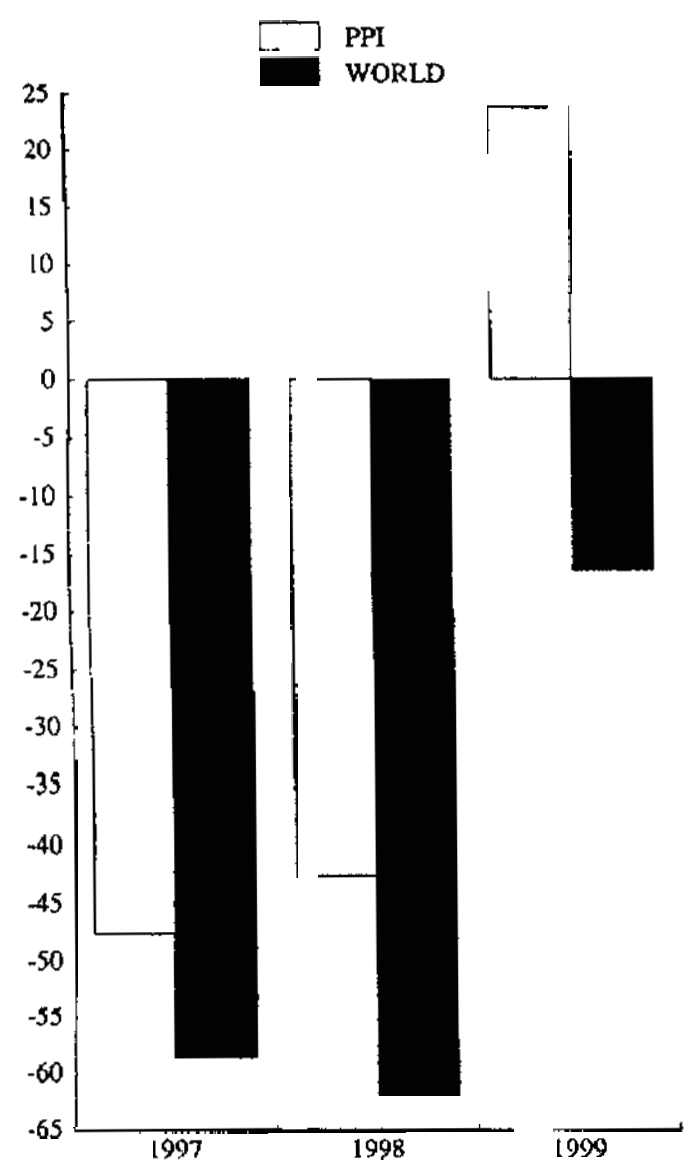

Other MOS Memory Chips

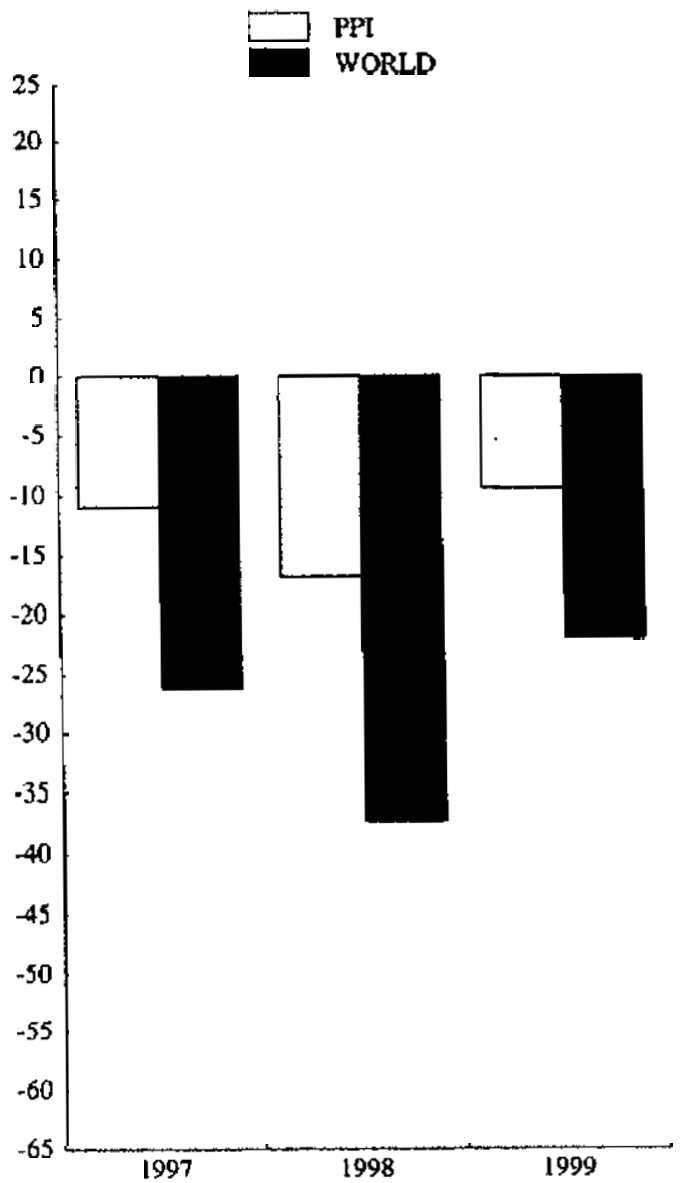




\section{Chart 2. Price Indexes for MOS Logic and Microcomponents}
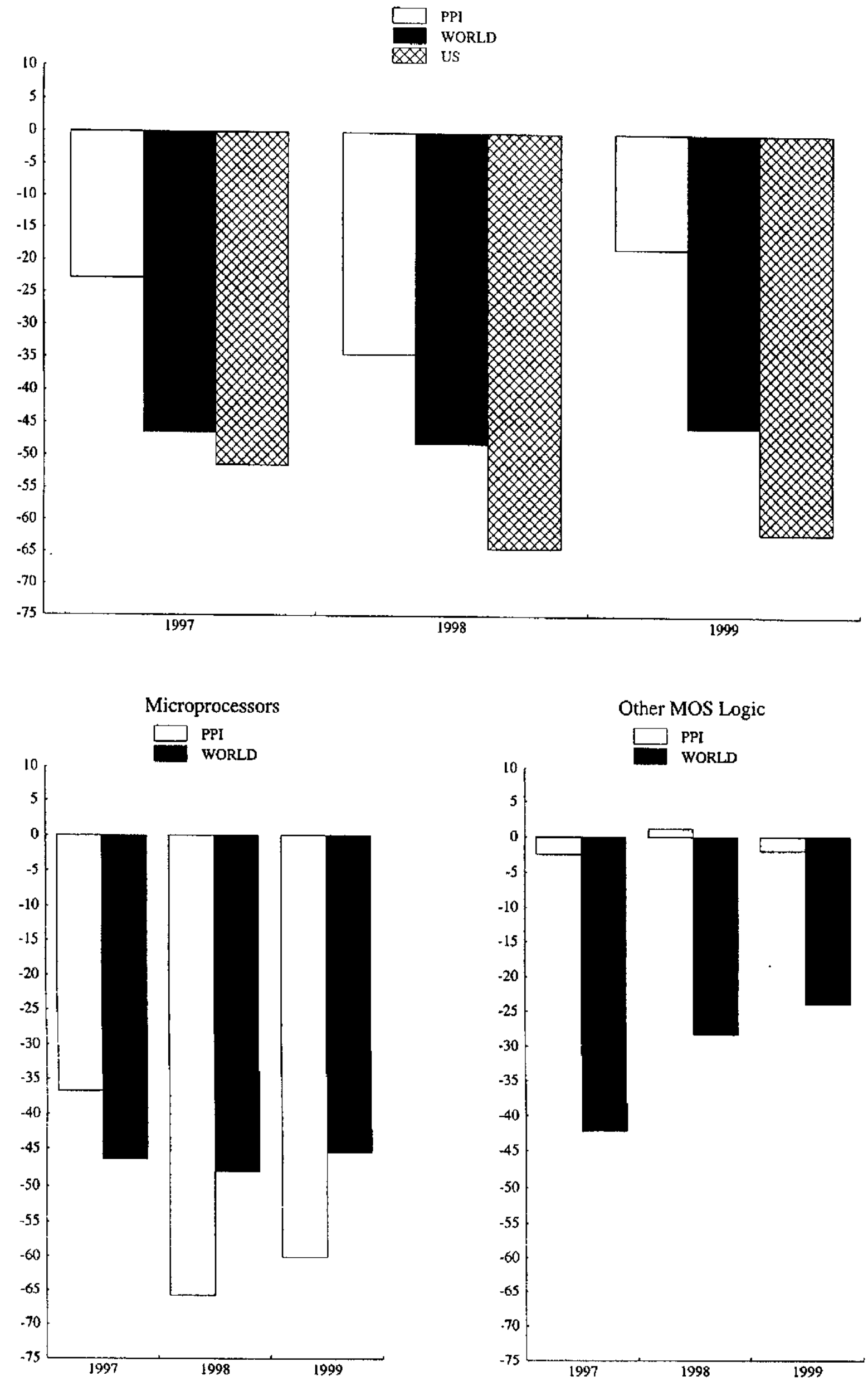


\section{Chart 3. Price Indexes for Other Integrated Circuits}

(Percent change, annual rate)

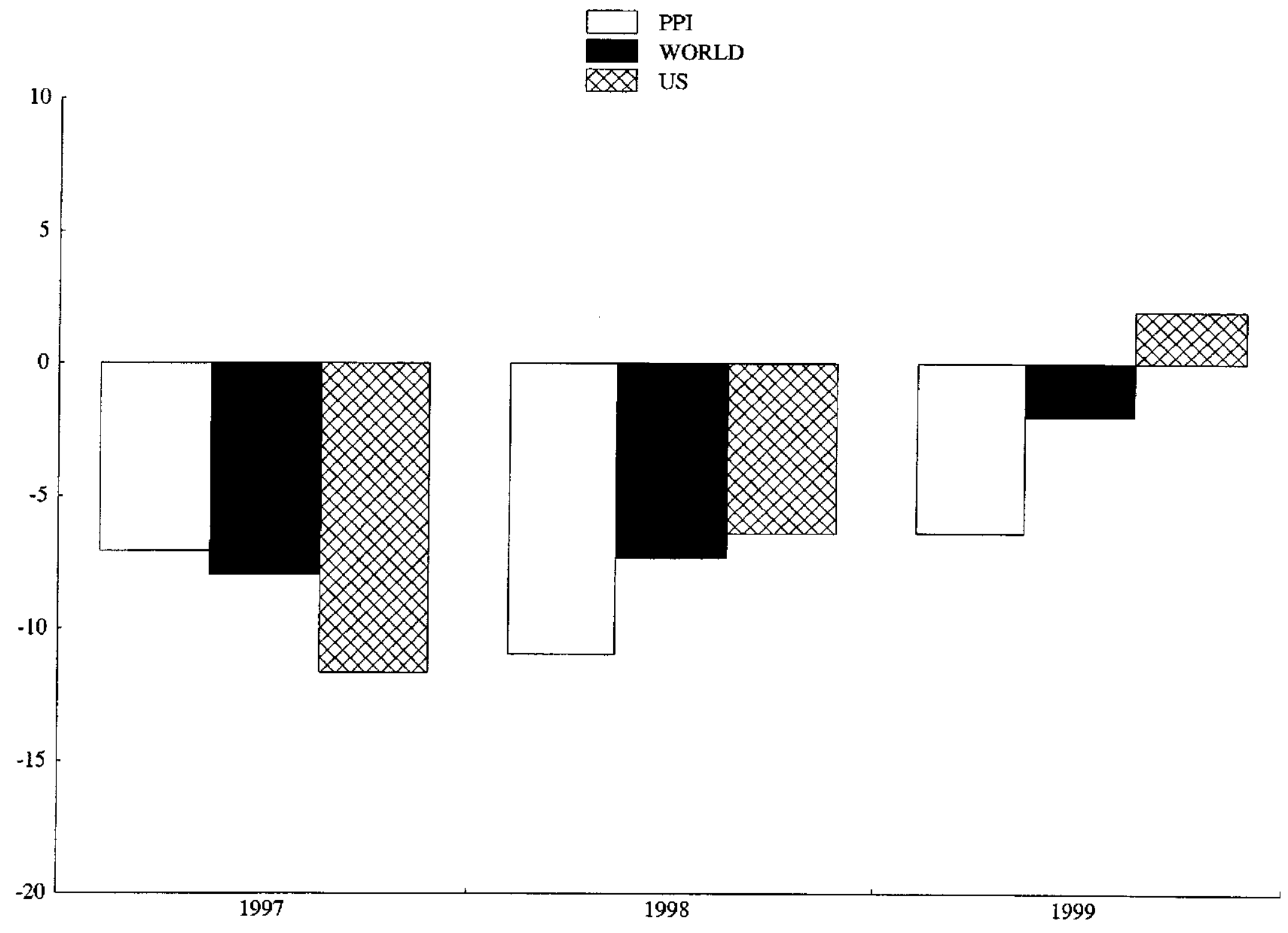

